Informal Logic

X.2, Spring 1988

\title{
Admit No Force But Argument
}

\section{MICHAEL J. WREEN Marquette University}

Much has been written in recent years about informal fallacies, and many people, this author included, have wanted to get beyond what has been rightly, even if somewhat pejoratively, called the standard treatment of them. Even so, detailed discussions of the individual fallacies (or better, putative fallacies) found in contemporary logic texts are, with the exception of petitio principii and argumentum ad hominem, relatively few in number.

Consider, for example, argumentum ad baculum, or appeal to force. Argumentum ad baculum is a fallacy, logic texts often claim, and consists in appealing to force in order to prove a point. Somewhat more rigorously, the fallacy is said to be committed if, and only if, "an arguer poses a conclusion to another person and tells that person either implicitly or explicitly that some harm will come to him or her if he or she does not accept the conclusion" "-that or something similar usually does duty as a definition. But besides an example or two of the so-called fallacy and some passages in exercise sets-passages said to commit the fallacy-there's little to report on ad baculum. The professional literature on the argument-type is scant, in other words, ${ }^{2}$ and so I hope I'll be forgiven for doing what I'm about to do here, namely criticize a recent piece-a good recent piece-on the argument-type. My excuses are, first, that the piece is a good one and, second, that I hope to contribute something to the ongoing discussion of ad baculum and, perhaps by implication, other (so-called) informal fallacies as well.

\section{I}

The article I have in mind appeared in these pages in 1980, and is by Charles Kielkopf. Kielkopf thinks, as do I and a number of others, that textbook treatments of ad baculum are superficial; but, unlike most of us who share the view, he's gone on to offer a diagnosis: the superficiality is due to "a failure to distinguish between reading a conclusion primarily as a description as opposed to reading it primarily as a prescription." 3 Consider, he says, the following reconstructed argument:

Lifting the sanctions [against ZimbabweRhodesia] would be regarded as a hostile act towards Afro-Arab nations.

Afro-Arab nations can produce serious economic and political problems for the U.S. and Britain in response to hostile acts.

(Therefore), the U.S. and Britain should not lift their sanctions against Zimbabwe-Rhodesia. ${ }^{4}$

The conclusion here is certainly everything I could wish for, since Kielkopf, unlike the authors of so many logic texts, has correctly identified not only the conclusion of the particular argument under consideration here, but also the proper form of conclusions of argumenta ad baculum in general: a 'should' or 'ought' statement, with some particular individual or group as the subject of the 'ought' or 'should.' Realizing that that's the form of the conclusion of such arguments itself goes a long way toward understanding them and, more importantly, correctly evaluating them. The primary evaluative question to ask of such 
arguments, given that this is so, will thus be: Do the premises support the particular 'ought' or 'should' statement being argued for? That question certainly can't be answered by determining whether the person offering the argument is threatening someone, or appealing to force in some way. (Not that I think that an ad baculum necessarily involves a threat or an appeal to force; but why I think as much is a tale better told elsewhere. ${ }^{5}$ ) It can be answered only by determining, as usual, the evidential relation between premises and conclusion.

Moreover, Kielkopf shows a good understanding of the premises of argumenta ad baculum. Good but not perfect, I think. Even better would be to have

If the U.S. and Britain lift the sanctions against Zimbabwe-Rhodesia, their doing so would be regarded [by various nations] as a hostile act, and so probably lead to serious economic and political problems for the U.S. and Britain.

The U.S. and Great Britain do not want such problems; (or better) such problems would be an evil the U.S. and Britain would suffer.

as the argument's premises; for then, with a premise like my first, action (in this case, the U.S. and Britain's lifting sanctions against Zimbabwe-Rhodesia) and state of affairs (economic problems of an unspecified nature for the U.S. and Britain) are distinguished, but the relation between them captured in a conditional statement. Similarly, the valuational nature of ad baculum is made explicit by the second premise, itself a valuational statement, and one concerning not the action but the state of affairs mentioned in the preceding premise. Finally, the inductive nature of ad baculum is made evident by the reconstruction-an important fact, I think, since even if all ad bacula are fallacious, our criteria for thinking so shouldn't be, in fact have never been, deductive criteria.
Thus I think Kielkopf's reconstruction of the argument's premises, though a decided improvement on textbook treatments of ad baculum-where all too often no reconstruction of premises or conclusion is offered at all-can itself be improved upon.

\section{II}

What's the verdict on the argument, then? According to Kielkopf,

a superficial analysis is offered if it is merely claimed that the Afro-Arab foreign ministers have argued fallaciously because they threatened the U.S. and Britain. The relevance, or irrelevance, of their threats to whether we should lift the sanctions depends upon how we read the conclusion.

This is the key to Kielkopf's diagnosis, then: the conclusion of the argument is ambiguous, and whether the argument is fallacious hangs on how the ambiguity is resolved.

If we read the conclusion as telling us that as a matter of sociological fact our standards or conditions for justifiable lifting of the sanctions have not been met, the appeal to force is fallacious. The fact that we will suffer if we act as if our conditions for lifting the sanctions have been met is not a relevant reason for concluding that these conditions have not, in fact, been met. So, when 'The sanctions should not be lifted' is read as primarily descriptive in the way just suggested, the ministers' appeals to force are fallacious; they argue fallaciously in giving them while we would reason fallaciously by accepting them. Still, the conclusion can be read as primarily prescriptive. When [so read], it directs us primarily to act in a certain way, viz., not to lift the sanctions regardless of whether... our conditions have been met. On the primarily prescriptive reading... attention focuses on an action with some probability of being performed. ... Clearly, what someone else may do to us if we act in a certain way is relevant to whether or not we act in that way. The threats of those foreign ministers provide relevant reasons for... not acting. They do not argue fallaciously by offering us such 
threats nor do we think carelessly if we heed such reasons, viz., threats.

Basically, what's being argued here is that 'The sanctions should not be lifted' isn't well warranted if read descriptively, but that it is well warranted if read prescriptively. The importance of the distinction between descriptive and prescriptive readings, moreover, extends far beyond the case at hand, Kielkopf thinks, for the results achieved here can be generalized, further defended, and applied not just to all ad bacula, but to all arguments with a certain sort of normative conclusion:

In general, a normative type of conclusion: $x$ should be done, can be read as primarily descriptive or... primarily prescriptive. Read descriptively such a conclusion claims that the action $x$ meets certain, usually unstated and vague, standards. When read descriptively we look to the premises for reasons for thinking that... action $\mathrm{x}$ meets these standards. Read prescriptively such a conclusion directs us to do $\mathrm{x}$ or, if we are giving the argument, directs our intended audience to do $\mathrm{x}$. When read prescriptively we look to the premises for reasons for doing $\mathrm{x}$; we want consideration of the premises to move us or our audience, i.e., to be a causal factor leading us or our audience, to do $\mathrm{x} . .$. It is not illogical to try to use... force... to cause action or to be caused to act... We have to distinguish carefully between considerations which are irrelevant as reasons for thinking but which are relevant as reasons for acting. ${ }^{6}$

Four comments on this diagnosis. First, suggested in this passage, especially in the third- and fourth-to-last sentences, is that an ad baculum is, of necessity, a two-person (or a two-or-more-person) affair: there is at least one person who offers the argument, and at least one, and a different one, to whom it is addressed. Actually, that needn't be so. It's possible to address an ad baculum to oneself, say, by arguing quite seriously (but elliptically), "If I don't get those papers graded before I go home tonight, no afterdinner dessert." A high-principled soul, maybe even a philosopher or two today, could offer-many have offered, in the past, I feel sure-just such an argument. But a second person isn't needed for another reason, I think: an argumentum ad baculum can be directed to languageless creatures, or at least some of them, at least if the notion of offering an argument is construed relatively broadly. Upon seeing you approaching him with a rolled-up magazine in hand and anger in eye, Old Bowser, paws just placed on the top of garbage can, would certainly know that he should get a move on. If we think of offering an argument as simply offering a reason, or reasons, for a conclusion, where such offering is conceptual or concept-laden in nature, we can say that the furry one knows that you're arguing (in effect) "Get away from that garbage can, and do it fast, or I'll swat you." An appeal to his (limited) reason has been made, and he knows as much, understands the argument (again in his limited way), and, we'll say, even acts accordingly. Old Bowser knows that the ad baculum is a good one. Not every threatening gesture made in the direction of every creature need be construed as an ad baculum, though, as not every such gesture is concept-laden. Some creatures don't have the cognitive wherewithal to offer genuine reasons to others, or to understand them when offered them themselves, but they can still threaten the welfare of others, or have their own welfare similarly threatened.

Second, and again in relation to the third-to-last sentence quoted: although the conclusion of a properly reconstructed ad baculum is an 'ought' statement, the arguer needn't want to, or be trying to, move someone, or cause someone to do something. The purposes of arguers are many and sundry, and an ad baculum can be offered with virtually any intention in mind, or even none, no overarching intention at all. If one of the Twelve Disciples had said to Jesus, "Jesus, if you don't flee the city within the hour, you'll be arrested, tried, and probably crucified," he needn't want Jesus to leave town. He might simply be making sure that 
Jesus is apprized of his predicament, and/or making sure that Jesus is the man (deity?) he thinks he is. The argument might be offered, in other words, with no intention to move Jesus, and perhaps even in the hope that its conclusion, that Jesus ought to leave town, won't be acted upon. In fact, to get really perverse about the matter, it might be offered with no definite hope or intention in mind at all, but simply to see what Jesus will do; or more far-fetched still, offered in a distrait, thoughtless manner, with Jesus's disciple simply talking out loud to himself as he runs over considerations in his own mind.

Third, and focusing more now on the unique and original details of Kielkopf's interpretative-evaluative diagnosis, the concept of prescriptive meaning-entailed by the notion of a prescriptive reading-is hardly clear. All we're really told about it is that it "directs our intended audience to do x." That sounds more like a speech act-though one imputed to a sentencethan a mode of meaning. Failure to clarify the notion and make it precise is probably one of the main reasons it has been largely abandoned in philosophic circles. Besides, the concept of prescriptive meaning is inherently odd, I think, as the prescriptive; at least, as a concept used to classify sentences, it seems more a syntactic than a semantic notion.

To be clear about the matter here, my main point is that since the notion of prescriptive meaning is absolutely essential to Kielkopf's diagnosis of ad baculumand his partial vindication of it-the concept should be clear, well-explained, and theoretically sound, or else Kielkopf should make at least a bit of an effort to establish its credentials. But the concept comes to us without its papers in order-much the opposite, in fact-and Kielkopf's attempt to put them in order is only minimal and not at all convincing.

'Descriptive meaning' is at least a little clearer, but as explained by Kielkopf, the notion conflates the criteria for believing or accepting a statement with the meaning of the statement-an important distinction as far as valuational statements in general are concerned, and an absolutely essential one as far as ad baculum is concerned, at least if the diagnosis that $I$ tender in the next paragraph is correct.

Fourth and last, there is a possible ambiguity in the conclusion of Kielkopf's argument, just as he says there is; but the ambiguity doesn't lie, as he has it, in descriptive versus prescriptive meaning (assuming the latter notion can somehow be made clear). Rather, the possible ambiguity concerns the word 'should': is it the 'should' of self-interest, or morality, or law, or what? Each of these 'should's has different criteria for application, and judging one and the same action by them, we may conclude, in some cases, that an action should be done-from one point of view-and shouldn't be done-from another point of view. Until we know which point of view the action is being judged from, assessment of the argument is, strictly speaking, impossible. None of this helps to salvage Kielkopf's reconstructive program, however, for none of it lends any support to his distinction between descriptive and prescriptive meaning, or helps to vindicate his central claim that whether or not an ad baculum is fallacious depends on whether reasons for thinking or reasons for acting are in question. To address this latter claim directly now, but to put the point somewhat inaccurately: sometimes reasons for thinking (or believing) are reasons for acting, namely when, in the case of an ad baculum, the argument has any strength at all. But to be somewhat more accurate about the matter: the real question is simply whether an argument's premises provide strong support for its conclusion, once that conclusion has been properly understood-that is, as far as the case at hand is concerned, once the 'should' that figures in the conclusion of the reconstructed ad baculum has been properly identified. Descriptive and prescriptive meaning have nothing to do 
with it. ${ }^{7}$

Let me illustrate with an example or two. Suppose that someone argues:

I'm not sure that you should submit your proposal. If you do submit it, [Ralph?] Johnson will have to criticize it in defense of his own idea. You know Johnson has more experience here than you do, and I'd hate to see him embarrass you in front of the other employees. ${ }^{8}$

Here the reconstructed conclusion is "You ought not to submit your proposal," with the 'ought' probably being one of selfinterest. However, if the argument were, "If you don't improve the lot of Blacks and meet their demands, there'll be riots," "9 the argument being addressed to a secure politician, say, then the 'ought' in the reconstructed conclusion, "You ought to improve the lot of Blacks and meet their demands," should probably be understood as that of morality. The nature of the values in question determines the kind of 'ought' under consideration: moral values, a moral 'ought'; self-interested values, a prudential 'ought'; aesthetic values, an aesthetic 'ought.' The easiest way to see what sort of 'ought' is in question is to preface the reconstructed conclusion with 'From the point of view,' or with 'As far as values are concerned,' and then to see whether, in context, that makes good sense. Try an argument with an aesthetic 'ought', then: "That waterfall sure is nice, and I'd hate to see anything happen to it. Things can happen, though, if you don't look the other way when it comes to violations of the building code." Here the reconstructed conclusion is "You ought to look the other way when it comes to violations of the building code," with aesthetic reasons, reasons having to do with perserving the aesthetic value of the waterfall, being offered as support.

\section{III}

Nothing like a complete account of ad baculum has been offered in this paper, of course, but a short summary of my findings and 'suggestions'-suggested but not explicitly drawn conclusions - might still be in order.

Many everyday ad bacula find expression as a single statement, frequently in the form of an imperative-statement disjunction, "Do $\mathrm{x}$ or such-and-such will occur," or an imperative-statement conditional, "If $p$, then do (don't do) x." Understanding and assessing the argument, then, frequently requires reconstruction. Proper reconstruction yields an argument whose basic form (without going into too many details here) has two premises and a conclusion. One premise is conditional and descriptive of two non-valuational states of affairs (one of which is an action); the other premise is categorical and valuational and concerned with one of the states of affairs (the non-action-al one, so to speak) detailed in the other premise. The conclusion is an 'ought' statement whose subject is a person (or some other creature capable of action) and whose content concerns the state of affairs not described in the second premise. When reconstructed and carefully evaluated, most everyday-life ad bacula-such as "Pick up that piece of paper, or I'll punch you in the mouth" and other arguments of a similar ilk-turn out to be fairly strong, usually as strong as the people who offer them. Certainly the examples usually found in logic texts-if they're not the product of the author's imagination-fare quite well. ${ }^{10}$ There is, then, no general fallacy of ad baculumwhich is to say, no argument can be condemned as fallacious just because it's an ad baculum.

Many other things authors of texts and at least one theorist of the argument have said about it are inaccurate, too. Contrary to common opinion, an ad baculum needn't involve an attempt to cause someone to do something, and one can argue ad baculum with oneself, without the use of language, and to languageless creatures. The argument 
is not essentially dialectical, not in the everyday sense of the term, anyway, the sense in which two numerically distinct individuals are required. Even the 'ought' that figures in a reconstructed ad baculum's conclusion has few restrictions on it. It can be a moral or a legal 'ought', or any of a number of other 'ought's as well. Nor do the speech acts of warning or threatening have any inherent connection with whether an ad baculum is fallacious. A person can warn or threaten yet offer a strong argument-that's the case with most everyday-life ad bacula, I should think, the argument of our paper-picking bully of a paragraph back being, in normal circumstances, a case in point. Or a person can warn or threaten and offer a weak one, simply because his premises don't lend strong support to his conclusion-as would be the case if our litter-obsessed friend had the misfortune to offer his gem to Bruce Lee. Assessment of the argument is thus independent of speech act considerations.

Kielkopf's reconstructive program contains valuable insights but errors, too. He understands the form of a reconstructed ad baculum fairly well, but draws a misleading, in fact a bogus, distinction between reasons for thinking and reasons for acting as a criterion for assessing the fallaciousness of ad bacula. He also employs two concepts of dubious worth, prescriptive and descriptive meaning, as evaluative tools, and misunderstands the nature of ad baculum in other ways, too, though admittedly less important ways, evaluatively speaking.

One very important thing that Kielkopf does seem to realize, though, is that ad baculum is not a deductive argument. The premises of a reconstructed ad baculum could well be true but its conclusion false. That doesn't mean that all ad baculums are fallacious, however. What it means is that ad baculum is not a deductive argument. As an inductive argument, some of its tokens are very strong, some very weak, most somewhere in-between.
I hope to have advanced the dialectic on ad baculum somewhat, then, not so much by criticizing Kielkopf as by using his insights and building upon them-and also, of course, correcting his views when they seem to me mistaken. In addition, I've tried to take the discussion one step further by providing a bit more of a full-bodied theory of the argument-type than others have offered, even if I haven't considered every aspect of the ad baculum. You can force me to do only so much.

And if you don't believe what I have written here, your subscription to Informal Logic will lapse immediately. ${ }^{11}$

\section{Notes}

1 Patrick Hurley, A Concise Introduction to Logic, second edition (Belmont, California: Wadsworth Publishing, 1985), p. 102.

2 Scant, but not non-existent. Discussions of note include Dwight Van de Vate, "The Appeal to Force,' Philosophy and Rhetoric 8 (1975): 43-60; George Yoos, "A Critique of Van de Vate's 'The Appeal to Force', 'Philosophy and Rhetoric 8 (1975): 172-76; John Woods and Douglas Walton, "Ad Baculum," Grazer Philosophische Studien 2 (1976): 133-140; Douglas Walton, Logical Dialogue Games and Fallacies (Lanham, MD: University of America Press, 1984), pp. 36-37; John Woods, "Ad Baculum, Self-Interest and Pascal's Wager," in Frans H. van Eemeren, Rob Grootendorst, J. Anthony Blair, and Charles A. Willard, eds., Argumentation: Across the Lines of Discipline (Dordrecht, The Netherlands: Foris Publications, 1986), pp. 343-49.

3 Charles Kielkopf, "Relevant Appeals to Force, Pity, and Popular Pieties," Informal Logic Newsletter 2 (1980): p. 2.

4 Ibid., pp. 2-3. 
5 I tell it in "May The Force Be with You," Argumentation 2 (1988): 425-440.

6 Kielkopf, op. cit., p. 3.

7 Of course one could claim, along with some of the logical positivists, that all 'should' statements are really disguised imperatives, and so all ad bacula are really fallacious. But the claim that 'should' statements lack a truth value has little more than the much criticized verifiability theory of meaningfulness to say for it, and much to be said against it - and that regardless of whether values are (ultimately) conventional or not. See my "Not Even Relatively Robust,", Philosophy and Phenomenological Research 43 (1982): 83-89, for a critique of the view that certain selected judgments (or statements) are neither true nor false.
8 Robert Paul Churchill, Becoming Logical (New York: St. Martin's Press, 1986), p. 438.

9 Nicholas Capaldi, The Art of Deception (Buffalo, N.Y.: Prometheus Books, 1974), p. 140.

${ }^{10}$ See "May the Force Be with You," op. cit., and "A Bolt of Fear,"' Philosophy and Rhetoric (forthcoming).

${ }^{11}$ My thanks to an anonymous referee, Nancy Davlantes, Christopher Tindale, and Walter L. Weber for their useful comments on an earlier draft of this paper. Weber's biting comments were themselves a useful ad baculum.

Professor Michael J. Wreen, Department of Philosophy, Marquette University, Milwaukee, Wisonsin 53233. 